\title{
Modelling of Regional System of Budget Resources Management
}

\author{
R. R. Gaizatullin ${ }^{1}$, Ramil R. Gaizatullin ${ }^{1}$, Ilnur N. Vafin ${ }^{1} \&$ E. N. Zagladina ${ }^{1}$ \\ ${ }^{1}$ Kazan (Volga region) Federal University, Russian Federation \\ Correspondence: R. R. Gaizatullin, Kremlevskaya str. 18, Kazan, 420008, Russian Federation. E-mail: \\ sciene-kfu@mail.ru
}

Received: June 19, 2014 Accepted: July 25, 2014 Online Published: September 28, 2014

doi:10.5539/ass.v10n20p143

URL: http://dx.doi.org/10.5539/ass.v10n20p143

\begin{abstract}
The aim of the article is to establish theoretical-methodical foundation and practical recommendations that provide increase of effectiveness of inter-budgetary fiscal relations on the basis of development of instrument of the regional budgetary resources management in contemporary Russian economy. The article determines the contents of models of reforming of inter-budgetary fiscal relations as forms of realization of principles of budgetary federalism, establishes methodical approach for formation of regional budgetary resources on the basis of economic zoning, the authors developed methodology of formation of the regional model of budgetary resources management on the basis of use of indicators of social-economic development of the region.
\end{abstract}

Keywords: Russian model of budgetary federalism, budgetary resources, regional management system, subnational budget, economic zoning

\section{Introduction}

Vertical and horizontal imbalance of budgetary system sharpening contradictions between centrifugal and centripetal tendencies of development of the Russian federative state, from correlation between which the effectiveness of structural reforms greatly depends, are essential consequences of crisis, together with increase of national debt, performance degradation of the main macroeconomic national measures. Further development of relations in the system "centre-regions" is greatly connected with development of budgetary federalism; regional fairness interpreted as social fairness of distribution of limited resources concerning territory subnational entities is one of the main principles of this system. (Averianov, 2013) The shortcomings of Russian model of budgetary federalism are the following: unreasonable differences in ratio of coverage of expenditures of regional budgets by tax revenues with undeveloped methodology of distribution of transfers from the federal budget, which gives possibility to the center to manipulate budget transfers and which is the source of growth of regional disproportions; vertical imbalance of the Russian fiscal system connected with transfer of the part of social expenditures which are not secured by good taxation base, to the regional level; vicious system of "special budget conditions" which gives "asymmetrical shape" to the federative state, which reflects between norms of fiscal legislation declaring political and economic equal rights of subjects of Federation, and spontaneity of inter-budgetary fiscal relations formed under the influence of political environment, contradictions and compromises between the center and regions. (Bagautdinova, 2014) Besides, the following aspects interfere effective implementation of principles of budgetary federalism: essential differentiation of economic and fiscal potentials of the regions; limited ability of the majority of subjects of the Federation and local self-governing authorities to provide budgetary self-reliance; absence of horizontal contract mechanisms of fiscal equalization between subjects of relations; great social differentiation; absence of sufficient resources of the federal budget to equalize fiscal capacity of the regions in the frames of formalized procedures; great disproportion between transferred to the subnational level financial assets and responsibility for their use; excessive centralism of inter-budgetary fiscal relations; distortion of institutional conditions for economic and fiscal policy of regional and local authorities, etc. all this shows that the main contradictions between the center and regions are exactly in the fiscal sphere and they are real danger for integrity of the country. This predetermined the relevance of the research topic, its theoretical and practical importance. (Panasyuk, 2014)

Methodological basis of implementation of functions of fiscal federalism is connected with the theory of public finance which, in its turn, is the part of theoretical conceptions interpreting the mechanism of development of public sector economics. (Isaeva, 2013) While fiscal tax revenues were traditionally the subject of public finance, the theory of public sector economics was of general nature and, together with the taxation theory of, included 
the theory of public fiscal expenditures and theoretical foundation of inter-budgetary relations (distribution of income and expenditure between budgets of different levels). (Gainova, 2013) The following Russian and foreign economists made substantial contribution to the development of the theory and practice of regional budgetary resources management: Galitskaya S. V., Karchevskaya S. A., Khodorovich M. I., Shlygina E. V., Brown C., Jackson M., Diamond J., Musgrave R., Oates W., Tiebout Ch. And others.

\section{Methodology}

The statements formulated in the frames of the theory of regional economics, theory of budgetary federalism are the theoretical basis of the research. Formulation and proof of working hypotheses were carried out on the basis of scientific and special cognitive methods, including historical and logical analysis, principles of dialectics, systematic approach, statistical, graphical and economic-mathematical methods (Bagautdinova, 2013). Systematic approach to the problem under consideration was applied in the process of development of major issues of economic forecast, which allowed to provide comprehensive research and to identify the ways of efficiency and increase of effectiveness of budgetary resources management at the meso-level.

\section{Results}

In the result of the research the contents of models of reforming of inter-budgetary fiscal relations-according to the principles of fiscal federalism-was established: radical (single-channel) model, in the frames of which the income from tax revenues from the territorial subnational entity-in proportion 80:20-are respectively credited to sub-national and federal budgets; organizational model, in the frames of which the number of tax benefits reduces, channels of diverted revenues from the regional budget are liquidated, the work of the tax authorities, aimed at improving fiscal performance, becomes very active; the list of own sources of replenishment of the revenue side of the budget expands; evolutionary model which involves the budgeting in accordance with the specific indicators (LEDs) on the basis of the objectives and estimated figures of the socio-economic policy in the region (Tiebout, 1956).

The research allowed to justify the methodological approach to the formation of the budgetary resources of the region on the basis of economic zoning, and this allowed to justify necessity for introduction of an additional level of sub-regional budget that fully takes into account the territorial division of labor and provides the formation of optimal branch, territorial and reproduction proportions; it is a factor to meet the needs of the local community in public goods, the formation and of effective implementation of the resource, organizational and institutional capacities of regional education (Markov, 2013).

\section{Discussion}

Fiscal federalism is interpreted as the relationship between the federal authorities and the authorities of the Federation on the basis of combining the principles of centralism and decentralization concerning the formation and implementation of fiscal policy of the state, delineation of fiscal powers, expenditure and income distribution and redistribution in the budget system with a high degree of independence of budgets and responsibility for the results of, independent of fiscal policy carried out by regional and local authorities on the basis of the unity of national interests and the interests of the population, including the interests of the peoples of the multinational federation living on the territory of the subjects of Federation and constituent local territorial entities. The Russian model of fiscal federalism can be referred to the cooperative model with elements of decentralization (Budget Code of the Russian Federation).

Analysis of theoretical and methodological approaches to the formation of the budgetary resources management system, as well as the theory and practice of inter-budgetary relations, allowed to identify three models of their reforming (Brown, 1990), (Diamond, 2006), (Musgrave, 1959). The first model (radical or single-channel) is based on the implementation of the following conceptual statements: enrollment of the main part of taxes and fees received from residents of this territorial unit into the regional budget; transfer of the fixed share from taxes and fees to the federal budget (on the level of 20\%). The second model (organizational) presupposes measures connected with reduction of the number of tax benefits, the establishment and cutting off of the existing channels of diverting of revenues from the regions, activation of work of the tax authorities so to ensure the collection of taxes and sale of confiscated property, expansion of regional and municipal revenue sources of subnational and sub-regional budgets, qualitative change of methods of calculation of transfers to the subjects of the Federation (Sarkin, 2013). The third (evolutionary) model of inter-budgetary relations reform presupposes assignments from regulatory taxes and allocation of funds from the budgets of the higher level in various forms, which is the development of inter-budgetary mechanism of inter-budgetary control used in Russian today (Budget Strategy of the Russian Federation for the period up to 2023). 
In conditions of the transfer from "management of budgetary expenditures" to "management of results" the budgeting should be linked to specific indicators (indicators) on the basis of the objectives and expected results of the regional socio-economic policy. When planning costs the main attention should be paid to verification of final results within the budget programs, allocations should be clearly linked to the functions they perform. (Oates, 1972)

The study allowed to make the conclusion concerning the feasibility of introduction of the additional sub-regional fiscal level of the budget in the subjects of the Federation based on the principles of economic zoning, which is determined by the contemporary stage of the social division of labor, the deepening of which led to zonation of economic regions as parts of the regional entities. (Fakhrutdinova, 2014) Economic zoning of the Republic of Tatarstan is the illustration of this statement (Table 1).

Table 1. Structure of economic regions of the Republic of Tatarstan

\begin{tabular}{ll}
\hline Regions & Territorial structure \\
\hline Stolichny & $\begin{array}{l}\text { City of Kazan, Atninsky, Verkhne-Uslonsky, Vysokogorsky, Zelonodolsky, Laishevsky, } \\
\text { Pestrechinsky }\end{array}$ \\
Zapadny & Apastovsky, Buinsky, Drozzhanovsky, Kaibitsky, Kamsko-Ustyinsky, Tetyushsky \\
Severny & Arsky, Baltasinsky, Kukmorsky, Mamadyshsky, Rybno-Slobodsky, Sabinsky, Tyuliachinsky \\
Yuzhny & Aksubaevsky, Alkeevsky, Novosheshminsky, Nurlatsky, Spassky, Chistopolsky \\
Vostochny & Agryzsky, Aznakaevsky, Aktanyshsky, Bavlinsky, Menzelinsky, Muslyumovsky, Yutazinsky \\
Kamsky & Elabuzhskij, Zainsky, Mendeleevsky, Nizhnekamsky. Tukaevsky, city of Naberezhnye Chelny \\
Neftyanoy & Almetyevsky, Bugulminsky, Leninogorsky, Sarmanovskiy, Cheremshansky \\
\hline
\end{tabular}

The analysis allowed identifying the relationship of the principles of economic zoning and the order of formation of the revenue side of the budget due to tax revenues from profits. The grouping of companies allowed identifying five regions:

1) "Neftyanoy", which includes 14 biggest enterprises of the republic of Tatarstan, 12 of which belong-according to Russian Classification of Economic Activities-to the kind of economic activities "Hydrocarbon production and natural gas extraction", 1-to the to the kind of economic activities "Construction" and 1 - to the kind of economic activities "Retail".

2) "Kamsky", represented by enterprises of almost all kinds of activities. 33 big enterprises are located in the region, the majority of them belong to the kind of economic activities "Production of machinery and equipment"; in 2009 it was the growth of the level of profitability of sales.

3) "Stolichny", which includes 50 biggest enterprises from the rating of 100 biggest companies of the Republic of Tatarstan.

4) "Yuzhny", represented by two enterprises which belong to the kind of economic activities "Hydrocarbon production and natural gas extraction".

5) "Severny", represented by one enterprise which belongs to the kind of economic activities "Retail".

The study showed that great part of profitable enterprises is connected with "raw" nature of the economy. Thus, the economic region "Yuzhny" has the greatest profitability of sales. In connection with this the transition to innovative way of development requires redistribution of budget funds towards the development of high-tech industries.

The results of the rating indicate that the Kamsky economic region takes the first rank according to overall rating of estimated values of 10 main indicators of socio-economic development of the regions. With the account of importance of some indexes, such as personal income, unemployment level, satisfaction of population with quality of health care, education, housing and public utility services, share of private means of the population for payment of housing and public utility services, and others, the rating of economic regions of the Republic of Tatarstan takes the values presented in the table 2. The data obtained allow to set out the priorities concerning the distribution of budget funds for development of the regions in the following order with the account of the largest companies from the top 100 of the largest companies in the Republic of Tatarstan and the average values of their profitability: Kamsky-13.3\%; Stolichny-14.95\%; Severny-3.97\%; Neftyanoy-33.44\%; Yuzhny-62.56\%. 
A comprehensive investment program which aims at increase of the level of social-economic self-sufficiency of economic regions, can be developed for each of the selected economic regions.

Methods of forming the model of budgetary resources management involve the use of assessment indicators of economic self-sufficiency of the republic and its municipal districts (city districts).

Table 2. Score of indexes of the level of social-economic development of the regions of the Republic of Tatarstan

\begin{tabular}{|c|c|c|c|c|c|c|c|}
\hline Index & Stolichny & Vostochny & Severny & Kamsky & Zapadny & Yuzhny & Neftyanoy \\
\hline Income of population & 6 & 3 & 7 & 2 & 5 & 4 & 1 \\
\hline $\begin{array}{ll}\text { Level } & \text { of } \\
\text { unemployment }\end{array}$ & 6 & 3 & 5 & 4 & 7 & 2 & 1 \\
\hline $\begin{array}{l}\text { Satisfaction with } \\
\text { quality of health care, } \\
\text { education, housing } \\
\text { and public utility } \\
\text { services }\end{array}$ & 6 & 2 & 5 & 3 & 7 & 4 & 1 \\
\hline $\begin{array}{l}\text { share of private } \\
\text { means for payment of } \\
\text { housing and public } \\
\text { utility services }\end{array}$ & 1 & 4 & 6 & 7 & 2 & 3 & 5 \\
\hline $\begin{array}{l}\text { Working efficiency } \\
\text { rates of growth }\end{array}$ & 1 & 4 & 6 & 7 & 2 & 3 & 5 \\
\hline $\begin{array}{l}\text { Share of small } \\
\text { business in economic } \\
\text { structure }\end{array}$ & 4 & 5 & 2 & 7 & 1 & 3 & 6 \\
\hline $\begin{array}{l}\text { Share of innovation } \\
\text { production in volume } \\
\text { of sales }\end{array}$ & 4 & 5 & 2 & 7 & 1 & 3 & 6 \\
\hline $\begin{array}{l}\text { Rates of investment } \\
\text { growth }\end{array}$ & 7 & 4 & 3 & 2 & 6 & 5 & 1 \\
\hline $\begin{array}{l}\text { Availability of social } \\
\text { infrastructure }\end{array}$ & 6 & 5 & 4 & 7 & 3 & 1 & 2 \\
\hline Condition of ecology & 7 & 4 & 5 & 6 & 2 & 3 & 1 \\
\hline Rank & 2 & 4 & 3 & 1 & 5 & 6 & 7 \\
\hline
\end{tabular}

\section{Conclusion}

The vast majority of strategic objectives of socio-economic policy are beyond the one fiscal year period, and these objectives are included in the system of medium-term development programs of the region. In its turn, principles of results-oriented budgeting should be implemented in the medium-term budget planning. Future plans for the second and third year of the previous medium-term budget cycle will be the basis for the design of the first and second years of the current budget cycle, thus, there is the linking of the annual budget plan with the medium-term planning. Medium-term budget planning can be used for placement of government procurement for the long term and connected with this cost reduction of supplies for budgetary institutions. In the future, this tool will become one of the key elements of the budget process.

\section{Summary}

To achieve these goals it is necessary to solve the following problems: first, transition to the new legislatively approved methods of inter-budgetary fiscal relations through the establishment of regional funds of financial support of settlements, municipal districts (city districts), other funds and distribution of these grants; secondly, distinction between revenue sources and streamlining of expenditure powers of budgets of different levels on the long-term basis. And the securing of revenue sources on the long-term basis will encourage local authorities to pursue an active economic policy aimed at increase of the tax base. To ensure the most effective and least cost production of public and municipal services with fixing of them for the level of power that can provide optimal performance of these services is the purpose of delineation of expenditure powers on the long-term basis. In order to create the regulatory legal framework it is necessary to develop and introduce bills defining 
methodology of calculation of subventions concerning given to municipalities state powers for consideration of the legislative authority of regional powers. Third, encouragement of local authorities aimed at fiscal consolidation of local budgets and necessary reforms. To solve it, it is necessary to pass normative legal acts which define the methodology for monitoring of financial condition of budgets of municipal districts and quality of municipal financial management.

\section{References}

Averianov, B., Bagautdinova, N., \& Sarkin, A. (2013). Estimation of manufacturing enterprise development risks in process of operational activity. World Applied Sciences, 27(13), 202-206.

Bagautdinova, N., Safiullin, L., \& Badrtdinov, N. (2014). The Role of Consumer Expenses in Ensuring Forward Dynamics of the Russian Economy. Mediterranean Journal of Social Sciences, 5(12), 43-48.

Bagautdinova, N., Safiullin, L., \& Minnahmetov, R. (2014). Institutionalization of Firm Environment in Conditions of Growing Turbulence. Mediterranean Journal of Social Sciences, 5(12), 55-58.

Bagautdinova, N., Tsvetkova, G., \& Novenkova, A. (2013). The interaction of formal and informal market institutes. World Applied Sciences, 27(13), 58-61.

Brown, C., \& Jackson, M. (1990). Public Sector Economics. Oxford: Blackwell Publishers.

Diamond, J. (2006). Budget system reform in emerging economies: The challenges and the reform agenda. Washington, DC: International Monetary Fund. http://dx.doi.org/10.5089/9781589064744.084

Fakhrutdinova, E., Severyanov, O., Shigabutdinov, A., \& Fakhrutdinov, R. (2014). The crisis of 1998 in Russia: Political intervention and its implications. Life Science Journal, 11(6s), 442-447.

Gainova, R., Shaidullin, R., Safiullin, L., \& Maratkanova, E. (2013). Infrastructural Component in Maintenance of Competitiveness of Region. World Applied Sciences, 27(13), 97-101.

Isaeva, T., Safiullin, L., Bagautdinova, N., \& Shaidullin, R. (2013). Aspects of a multi-level study of competitive performance of objects and subjects of economic management. World Applied Sciences Journal, 27(13), 116-119.

Markov, V., Bagautdinova, N., \& Yashin, N. (2013). Improvement of instruments of the state cluster-based policy in the contexts of economic entities interrelation asymmetry. World Applied Sciences, 27(13), 130-134.

Musgrave, R. A. (1959). The theory of public finance: A study in public economy. New York: McGraw-Hill.

Oates, W. E. (1972). Fiscal federalism. New York: Harcourt Brace Jovanovich.

Panasyuk, M., Pudovik, E., \& Sabirova, M. (2014). Problems of labor market of modern Russia in conditions of stable economic growth. Life Science Journal, 11(6s), 487-489.

Sarkin, A., Bagautdinova, N., \& Averianov, B. (2013). Development and implementation of adaptive science-intensive manufacture management system based on management processes automation. World Applied Sciences, 27(13), 159-164.

Tiebout, C. M. (1956). A Pure Theory of Local Expenditures. Journal of Political Economy, 64(5), 416-424. http://dx.doi.org/10.1086/257839

\section{Copyrights}

Copyright for this article is retained by the author(s), with first publication rights granted to the journal.

This is an open-access article distributed under the terms and conditions of the Creative Commons Attribution license (http://creativecommons.org/licenses/by/3.0/). 